\title{
Power Quality Improvement using BOA based Custom Power Devices
}

\author{
Bhukya Krishna Kanth Naik I B Lakshmana Nayak ${ }^{2}$
}

${ }^{1}$ PG Student, Dept of EEE, Vikas College of Engineering, Vijayawada, India

${ }^{2}$ Associate Professor\& HOD, Dept of EEE, Vikas College of Engineering, Vijayawada, India

To Cite this Article

Bhukya Krishna Kanth Naik and B Lakshmana Nayak, "Power Quality Improvement using BOA based Custom Power Devices", International Journal for Modern Trends in Science and Technology, Vol. 06, Issue 07, July 2020, pp.:119-126; https://doi.org/10.46501/IJMTST060719

\section{Article Info}

Received on 17-June-2020, Revised on 28-June-2020, Accepted on 15-July-2020, Published on 22-July-2020.

\section{ABSTRACT}

In present scenario power quality is the major concern for electrical power system. In order compensate these problems lot of methods available in the market. This paper proposes application of custom power devices to power system. For achieving better power quality an UPQC and IUPQC is provided in this paper. Both UPQC and IUPQC is a structure of two filters such as, series and shunt filters. The causes for poor power quality of system is due to harmonics, power factor variations and changes in system voltage. The purpose of these converters is to mitigate the $P Q$ issues. The reference signals required for series and shunt converters of CPD system is generated with the help of conventional controllers and PWM controllers. The PLL used to match the phase sequence of converters. For obtaining better improvement in Power Quality this paper is implemented with one of the optimization technique such as Bull Optimization Technique (BOA). The purpose of BOA is used to control the DC Link Voltage of CPD. With the help of this BOA technique, the variations in voltage and current are reduced to enhance the power quality. The effectiveness of this proposed system with BOA technique is tested and verified using Matlab/Simulink environment.

KEY WORDS: Interline Unified Power Quality Conditioner (IUPQC), Bull optimization algorithm (BOA), UPQC, Power Quality, THD.

Copyright (C) 2020 International Journal for Modern Trends in Science and Technology DOI: https://doi.org/10.46501/IJMTST060719

\section{INTRODUCTION}

The latest power distribution system is fetching very susceptible to the various PQ (Power-Quality) problems [1]. PQ in distribution systems is a focal concern for industrial, commercial and residential purposes. Increased affair above this matter has run to quantifying $P Q$ variations, reviewing the features of power disturbances and specifying solutions to these power quality problems. PQ is mostly exaggerated by the increased usage of non-linear loads such as powered electronic equipment, variable speed drives, and electronic control gears. Indigent power quality can disturb the security, reliability, and efficiency of several categories of equipment. Many parts of PQ are harmonics; flicker and imbalance have turn out to be stern concerns. Furthermore, lightning strikes on transmission lines, switching of capacitor banks and several network faults can too instigate PQ problems [2].

In consequence of the growth of powered electronic devices such as Flexible AC Transmission System (FACTS) and custom power devices, deregulated power systems with multipurpose new-fangled control abilities have 
performed. Reasonably slight concentration, however, has been fervent to system sag enhancement [3]. It is recognised that FACTS-based devices, viz., SVC, STATCOM, and DVR can deliver an effectual solution to voltage sag difficulties. Therefore, a recent distribution system needs a better steadiness of voltage being provided and the current drawn which is an elemental viewpoint to the end user. One latest and the very assuring solution is UPQC (Unified Power-Quality Conditioner). UPQC is a custom power device that contains shunt and series converters linked back to back on the dc side and distributes with load current and supply-voltage insufficiencies. The shunt inverter delivers reactive power and harmonic rewards by injecting a shunt current to the load. The series inverter is used in the compensation of voltage related problems, for example, sag and fabulous in source voltage by interleaving a controllable series voltage.

Conveniently, UPQC has been ultimate solution to progress the $\mathrm{PQ}$ in the electrical distribution system. The control method is not suitable for UPQC system for the motive that the dc sources are exchanged by capacitors in the UPQC system [4]. Accordingly, there is a requirement to consider several PQ mitigation procedures to convalesce the quality of power supplied. This shortage can be overwhelmed by unique intelligent optimization algorithms known as heuristic approaches are executed to solve PQ distributions. Some sounds regarded optimization systems are Evolutionary Programming (EP), Genetic Algorithm (GA), Simulated Annealing (SA), Differential Evolution (DE), Particle Swarm Optimization (PSO) and Artificial Bee Colony (ABC), etc. The improvement of UPQC PQ problem in a viable environment includes in the minimization of power losses [5].

\section{PROPOSED METHODOLOGY}

The structure of Interline power flow controller is shown in figure 1. It consists of two back to back converters with a common dc link capacitor. These two converters are connected to two feeders of distribution system for maintain system conditions. In this case we consider two feeder system. The shunt vsc converter of system is connected to feeder- 1 and series vsc converter is connected to feeder-2. There is a boosting transformer is connected between series converter and transmission system to maintain the voltage levels. IUPQC can act as a (a) smart circuit breaker, (b) also acts as power flow controller between grid and microgrid to repay the active and reactive power references of the series converter [6].

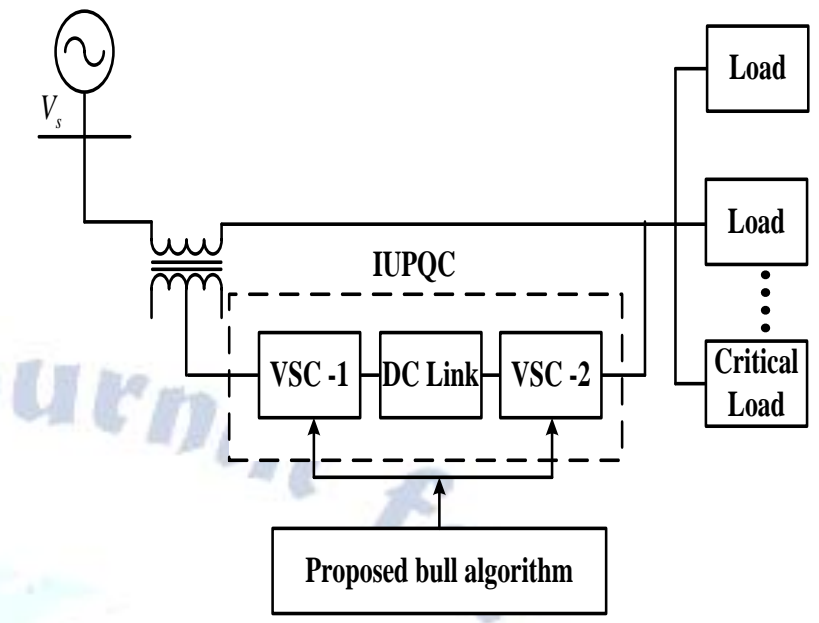

Figure 1:Structure of the proposed method

In the proposed method, the IUPQC is used to compensate the PQ issues with the help of the bull algorithm. The power sharing between the sources to the load is by achieves through maintain the dc link voltage. Initially, the normal voltage and current characteristics are analyzed, and then the $\mathrm{PQ}$ issues are created using the non-linear load, unbalanced load or critical load. The PQ issues are mitigated in the use of IUPQC device and bull algorithm is assist to the mitigation process via power sharing, dc link voltage regulation. The connected structure of IUPQC with distribution system is shown in figure 2 .

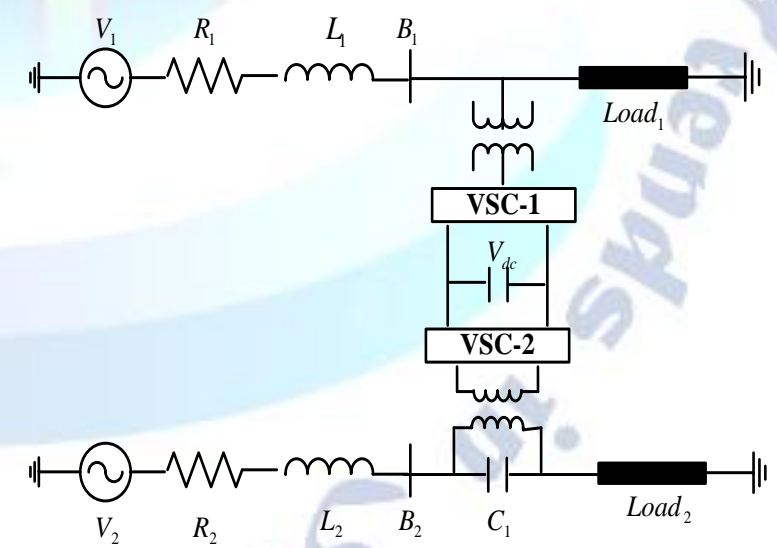

Figure2: IUPQC structure in the distribution system

Incidentally, the IUPQC exemplify a traditional power device that is effusively in employment in the distribution scheme to restrict the conflict that has an actual impact on the efficiency in function of the non-linear or critical load. Dependably, the IUPQC concealments the sequences active power filter (APF) over and above the shunt APF. The sequence APF effectual provides the compensation amongst the distribution scheme and the sub-transmission 
scheme affecting to the harmonics [7]. Into the bargain, the BOA algorithm assistance the regulation of voltage from the DC link capacitor. The power that the shunt section distributes or suck up, relaxes on the power conditions of the sequences compensator and the power mandatory to strip the losses. The detailed control process of the PAC control, series and shunt control techniques are described in the following sections.

\section{IUPQC CONTROL TECHNIQUES}

\section{A. Phase Angle Controller:}

The aim of the series inverter is to maintain the load voltage at desired limit. And also, it maintains the reactive power demanded by load is at constant. With the help of power angle, the series converter maintain the reactive power at fixed value under any circumstances i.e voltage variations or load changes. The phase angle is calculated based on the source voltage and load voltage. The phase angle is changed for reactive power control in the system [8]. The phase angle changed through the reactive power, the disturbances are compensated via the filters. The phase angle control phaser diagram is illustrated in figure3.

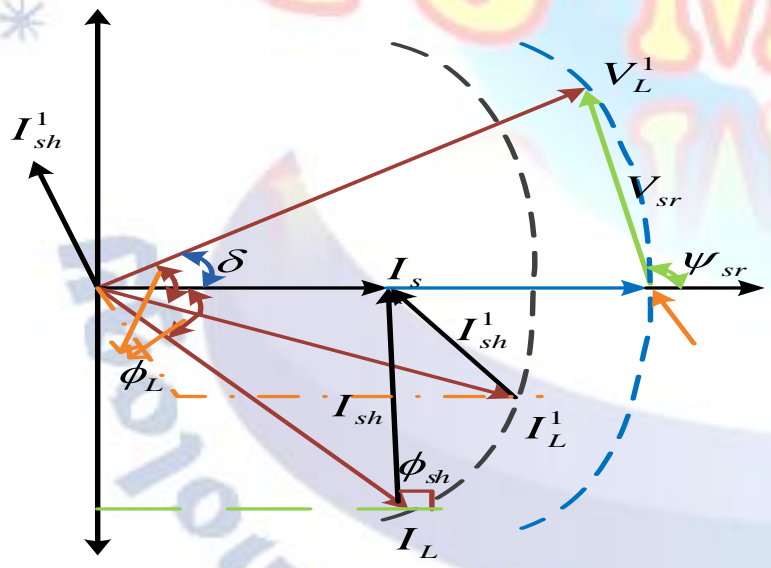

Figure3: Phasor diagram of the PAC control scheme

\section{B. Control Diagram of the Series APF controller}

The gate pulses required for series VSC is obtained by general PWM controller. And the reference voltage signals are obtained by controlling of dc bus and line voltage parameters. The magnitude required for reference signal is obtained with dc link voltage controller and required phase angle is to get with phase angle controller. The control diagram for series converter is shown in figure 4 .

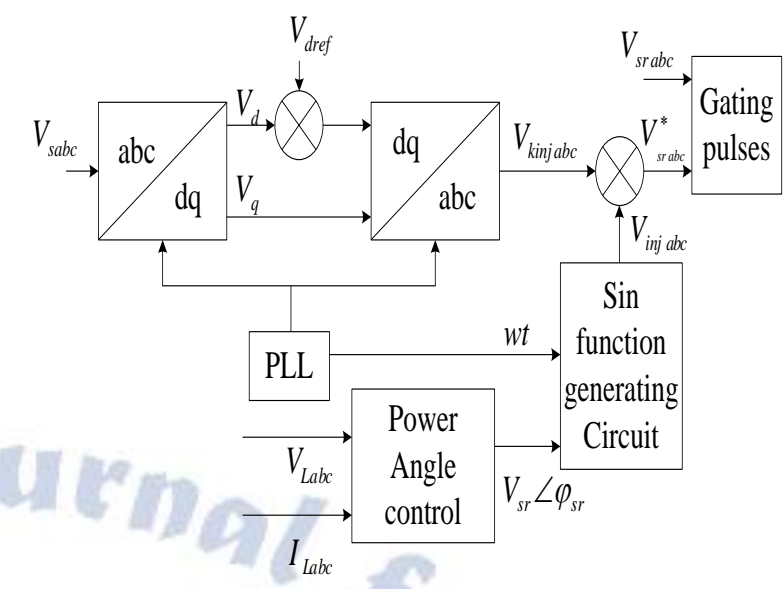

Figure 4: control structure of the series inverter

In this APF controller, the source voltage is transformed into dq-axis and that component is compared with reference direct voltage. Again, this error component converted to3-phase components. The combined value of error component and phase angle control value is applied to PWM controller for generating gate signals required for VSC.

\section{Controlling of the Shunt APF controller}

Here, PQ-theory method is used to generate reference current signals required for shunt apf controller. In this case, the actual load voltage and currents are converted into $a \beta$-coordinates. Form these coordinates, the active and reactive powers are to be calculated. These reference powers are compared with rated power and then converted to reference currents with the help of conventional PI controllers [9]. And Inverse Park's transformation is used for getting general abc components and applied to PWM controller to get gate signals.

The expressions for calculating powers using currents are shown below.

$$
\begin{aligned}
& p=v_{\alpha} \cdot i_{\alpha}+v_{\beta} \cdot i_{\beta}=\bar{p}+\tilde{p} \\
& q=v_{\beta} \cdot i_{\alpha}-v_{\alpha} \cdot i_{\beta}=\bar{q}+\tilde{q}
\end{aligned}
$$

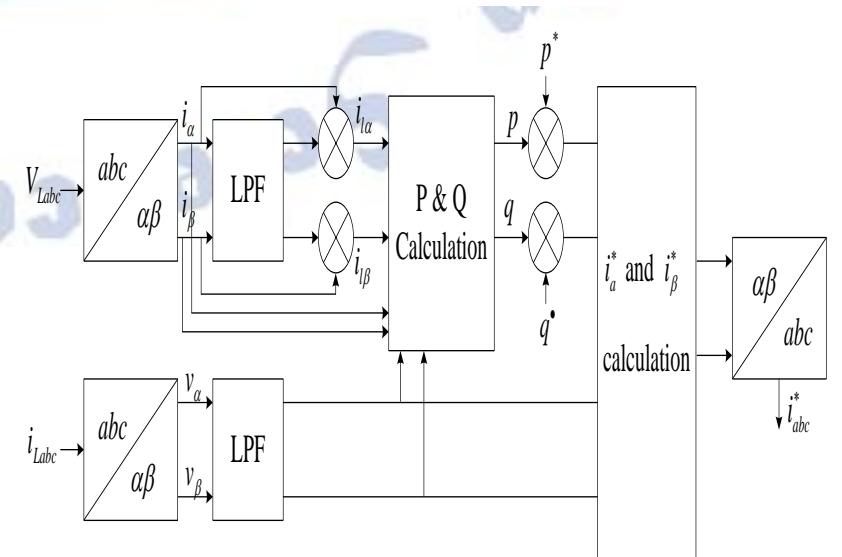

Figure 5: control structure of the shunt inverter 


\section{BULL OPTIMIZATION ALGORITHM}

The boa algorithm is utilized to hold the dc link voltage as a steady. The reference dc link voltage and regular dc link voltage is fed the enter of the set of rules. The error voltage or voltage difference of the dc hyperlink voltage is decreased and maintained inside the constant manner. Basically, the boa is the evolutionary algorithm. It is utilized the genetic operators, crossover and mutation. The proposed algorithm makes use of effective capabilities of the ga. One of the essential hazards of the ga is that it does now not use the great individual to provide a brand new technology. But, the satisfactory man or woman is actively used in the proposed set of rules. All individuals produced attempt to get better people via taking a certain part of the great man or woman. The choice algorithm that is the basic principle of the ga selects the first-rate people to be transferred into the new era. The individuals created on the initial stage live on by being mutated either until the fine end result is discovered or a sure iteration variety is reached [10]. The grade by grade method of the boa set of rules is given underneath.

\section{A. Initialization}

Initialize the population, i.e choose, the values of dc link voltage and reference voltages are initial commands with a limit of number $\mathrm{N}$ and Dimension D. The expression for initial population is shown below.

$$
X_{a b}=X_{b}^{\max }-R *\left(X_{b}^{\max }-X_{a}^{\min }\right)
$$

\section{B. Fitness}

The fitness is allocated based on the optimization problem. The dc link voltage is maintained equal to the reference voltage. It is denoted by the equation,

$V_{d c}^{*}=V_{d c}$

The dc link voltage is maintained by calculating the error voltage between, dc link voltage to reference dc link voltage are minimized. By the way of the dc link voltage control is achieved in the IUPQC device.

\section{Crossover}

Individual's technique the current quality solution received to date with the help of the manner of crossover. A two-factor crossover operation is used within the proposed set of rules. Random numbers named as $\mathrm{r} 1$ and $\mathrm{r} 2$ are generated for an individual with d dimensions of the dc link voltages. The variety of random variety is inside $[0, d]$.
If the random number $R_{1}$ is larger than $R_{2}$, then genes that belong to a certain individual are replaced with those of the best individual in $\left[R_{1}, R_{2}\right]$. Otherwise, genes that belong to a certain individual are replaced with those of the best individual in $\left[R_{2}\right.$, $R_{1}$ ]. If crossing points are close to each other in the crossover operation, then the individual performs more exploration. Otherwise, the individual performs more exploitation [11].

\section{Mutation}

The purpose is to find better people via doing research around the values of the gene inside the proposed algorithm. For the answer to transport forward fast and efficiently and to cast off nearby minima, the mutation system must play an energetic function. A gene of every character is mutated according to the mutation price. The mutation system is accomplished by way of using equation (6)

$$
M_{a b}=\left\{\begin{array}{lr}
X_{a b}+W * R_{1} * X_{a b}, & R_{2} \leq 0.5 \\
X_{a b}+W * R_{1} * X_{a b}, & O . W
\end{array}\right\} \text { (6) }
$$

\section{$E$. Settings and benchmark functions}

Take a look at the performance of the boa algorithm, the benchmark take a look at capabilities are applied. These functions include unimodal, multimodal, separable, non-separable, normal, and irregular check functions. This benchmark features set could be very massive, and those capabilities have different characteristics utilized in continuous problems. The usage of the benchmark features, the boa algorithm overall performance is evaluated based on [11].

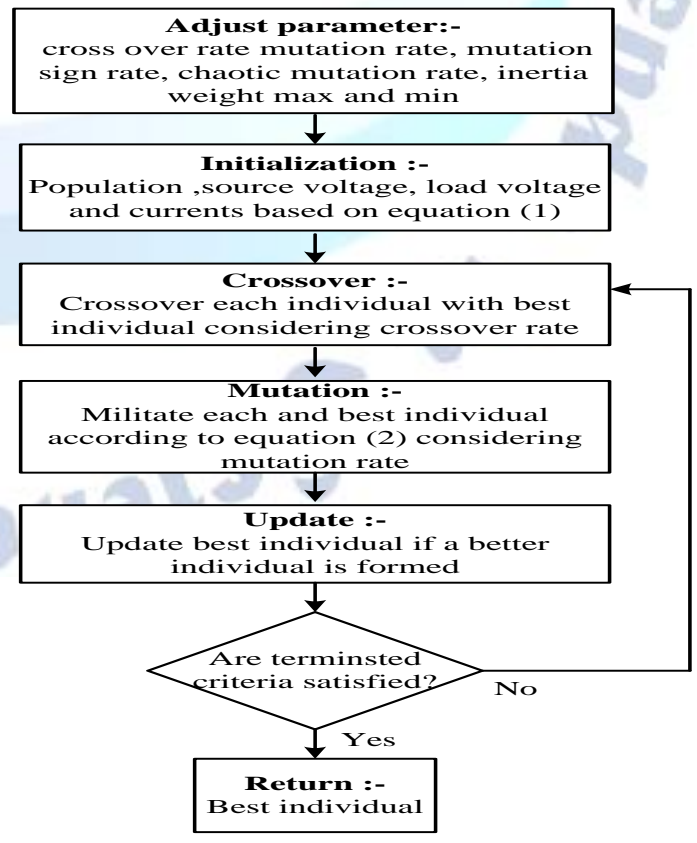

Figure 6: Flow chart of the BOA algorithm 
Based on the flow chart, the process of the bull algorithm is maintaining the dc link voltage of the both UPQC and IUPQC. The input is the dc link voltage and it is compared reference dc link voltage, the error value is minimized with the utilization of the BOA algorithm. By the way, the dc link voltage is maintained in the control system. The PQ issues are compensated in the utilization of the BOA with IUPQC device. The proposed controller results are analyzed and illustrated in the following section.

\section{RESULTS AND DISCUSSIONS}

The proposed method can be executed in MATLAB/Simulink working platform. At this point, the proposed method is actually based on CPD which is assisting the control for generating reference signals of the system. With this proposed method, voltage sag and swell problems tend to be compensating the sag appearance all the way through PAC control signals in distribution systems. Afterwards the controlled signals are produced from the proposed method that pulses can compensate the PQ issues in the utilization of the CPD. For that reason, the proposed method is also employed to enhance the performance of CPD not counting compensate the voltage sag and swell issues. The proposed method is experimented and its performance analysed. The performance analysis of the planned method is computed and explained in the following section.

Case 1: Proposed System with UPQC Controller

Unified power quality conditioning system (UPQC) consists of three VSCs in which two VSCs are connected in series to the two feeders and one VSC is connected in parallel to load end of the first feeder. These three VSCs connected back to back through a common dc-link capacitor. Each of the VSCs in Figure 2.12 is realized by a three-phase converter with a commutation reactor and high-pass output filter. The commutation reactor and high-pass output filter are connected to prevent the flow of switching harmonics into the power supply.

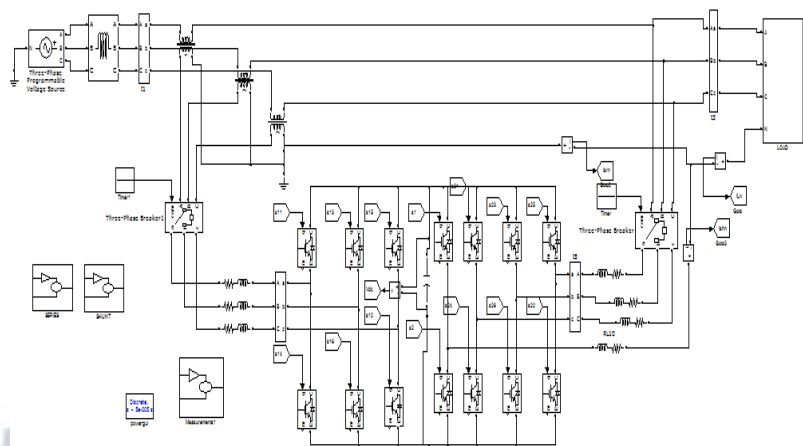

Figure 6: Simulink block diagram of UPQC

The purpose of UPQC is to regulate the load voltages against voltage sags, voltage swells and disturbances in the in the system and to compensate the reactive and harmonic components of nonlinear load currents.

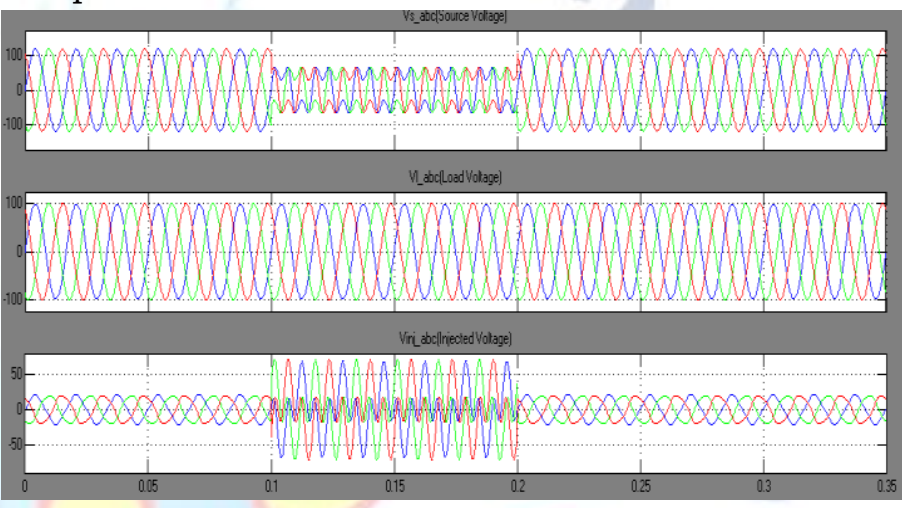

Figure 7: Simulation results using conventional topology. Terminal voltages with sag,

UPQC-injected voltages, and load voltages after compensation.

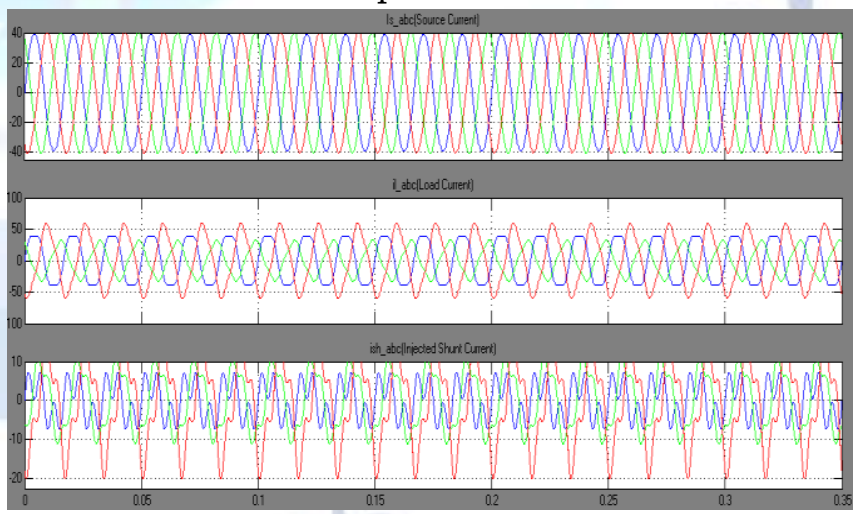

Figure 8: Simulation results using conventional topology. Shunt active filter currents

Figure 9: Simulation results using conventional topology. DC capacitor voltage 


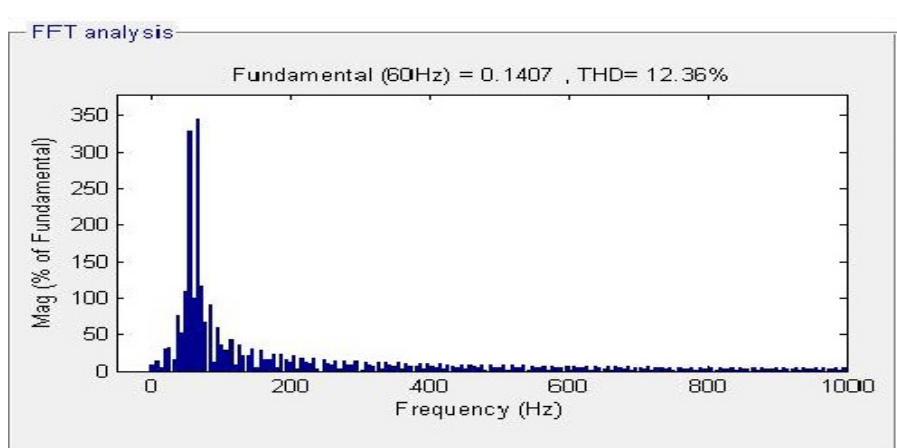

Figure 10: Total Harmonics Distortion for Grid Current

\section{A. Performance Analysis}

Figure 12 presents the normal behaviour of the distribution system current and voltage in the feeders 1 and 2. The PQ of the system along with non-linear load is enhanced because of the help of a proposed control technique based IUPQC.

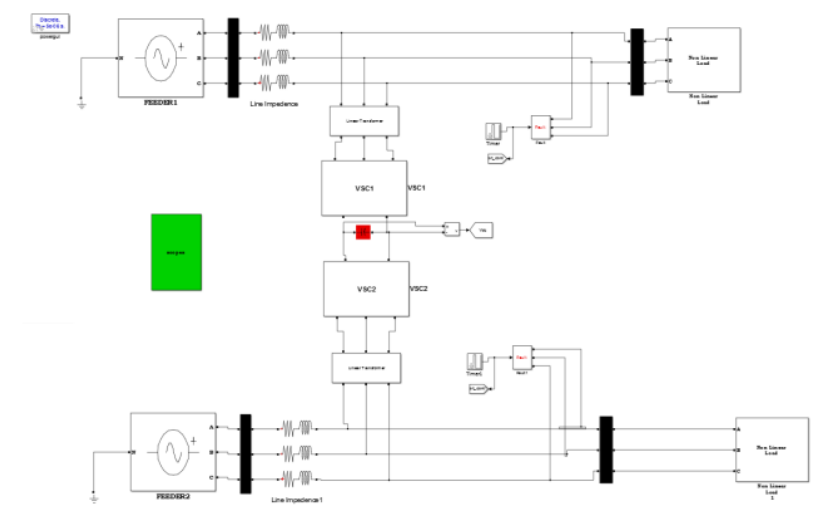

Figure 11: Simulink diagram of the IUPQC with proposed controller

\section{Case A:Swell at feeders 1 and 2}

The swell is initiated in the system use of the non-linear load, unbalanced load or critical load in the load side. The voltage swell signal is shown in Figure 9. The mitigation is achieved through the use of proposed controller.

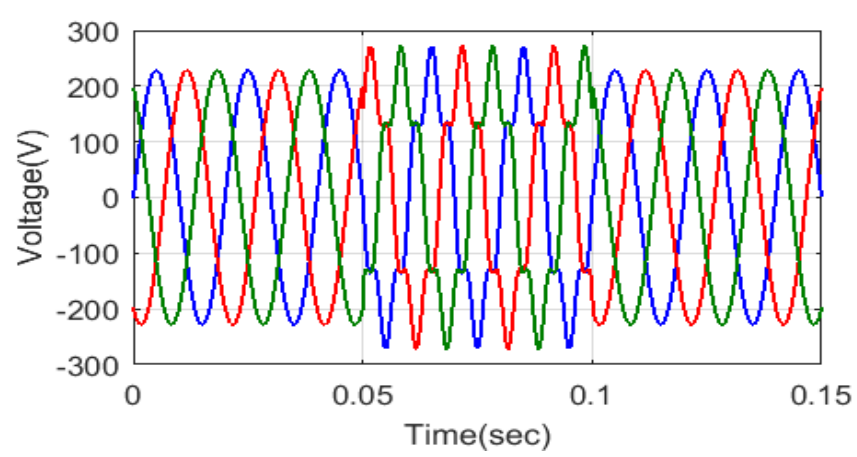

(a)

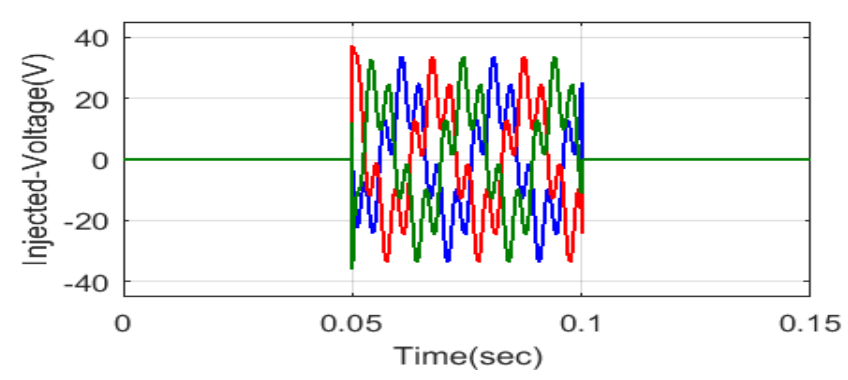

(b)

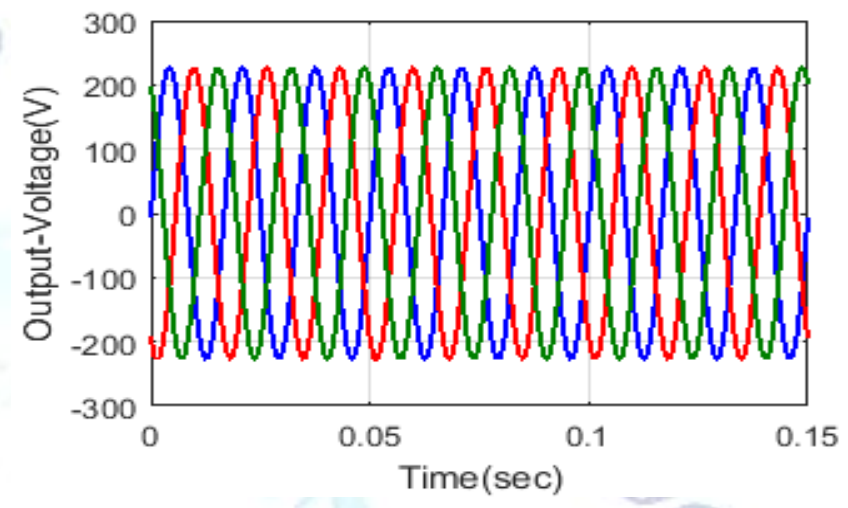

(c)

Figure 12: Analysis of the (a) Voltage swell, (b) Injected voltage and (c) Output voltage

Figure 12(a) illustrates the disturbance voltage. Initially, $230 \mathrm{~V}$ is maintained in the constant level to at $0-0.05 \mathrm{~s}$, then it is increased the voltage to $30 \mathrm{~V}$ (i.e. $260 \mathrm{~V}$ ) at $0.05 \mathrm{~s}-0.1 \mathrm{~s}$ due to the load variation. The increased voltage is compensated with the help of the IUPQC device through the series filter. The injected voltage from the series filter is $30 \mathrm{~V}$, it is compensated the voltage swell and the excess voltage is stored in the capacitor of the IUPQC is presented figure $12(\mathrm{~b})$. The compensated output is illustrated in the figure 9(c).Then the proposed BOA algorithm is utilized to maintain the dc link voltage as a constant level. The variation of the dc link voltage is illustrated in the figure 13.

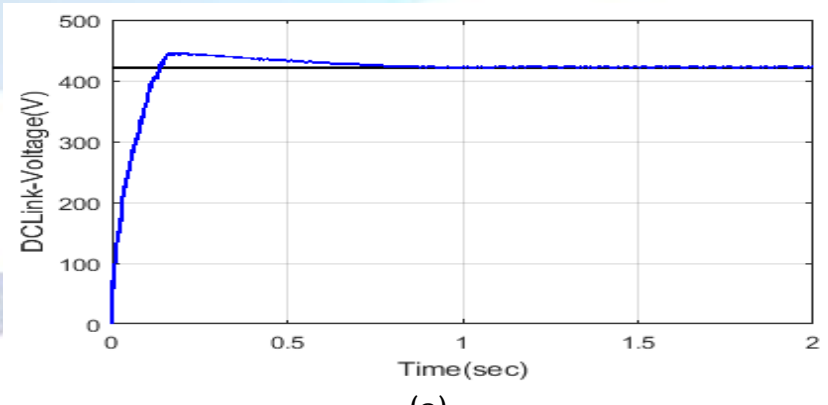

(a) 


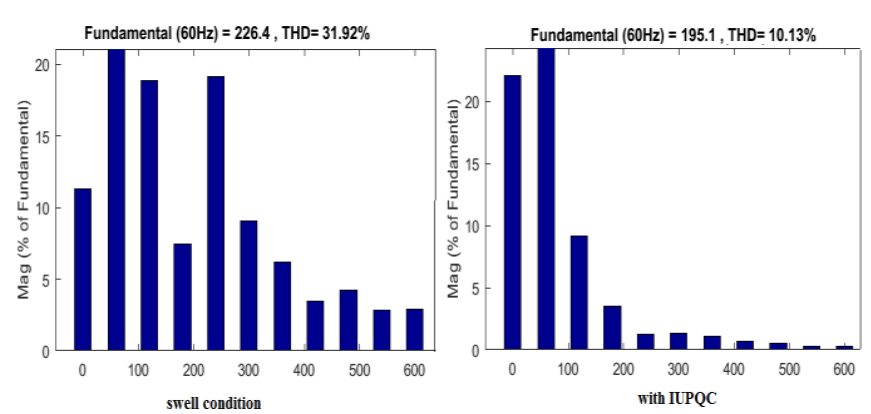

(b)

Figure 13: Analysis of the (a) dc link voltage and (b) THD ratio

Here, the dc link voltage level is $420 \mathrm{~V}$; the voltage is variation due to the disturbance. The voltage is maintained as constant it is illustrated in the figure 13(a). THD ratio is analyzed in the proposed method is illustrated in the figure 13(b). During swell condition the THD ratio is $31.92 \%$, it is minimized with the IUPQC to $10.13 \%$.

Table-1 THD Analysis for Load Voltage

\begin{tabular}{|c|c|c|c|c|}
\hline \multirow{2}{*}{ S.No } & \multirow{2}{*}{$\begin{array}{c}\text { Type of } \\
\text { Problem }\end{array}$} & \multicolumn{3}{|c|}{ THD (\%) } \\
\cline { 3 - 5 } & $\begin{array}{c}\text { Without } \\
\text { Controller }\end{array}$ & $\begin{array}{c}\text { With } \\
\text { UPQC }\end{array}$ & $\begin{array}{c}\text { With } \\
\text { IUPQC }\end{array}$ \\
\hline 1 & $\begin{array}{c}\text { Swell at } \\
\text { feeders } 1 \\
\text { and } 2\end{array}$ & $29.92 \%$ & $19.12 \%$ & $6.72 \%$ \\
\hline
\end{tabular}

The THD is analyzed for the load voltage under three different cases with UPQC and with IUPQC controllers. The comparative analysis for harmonic distortion is shown in table-1. From the table, it conclude that UPQC based IUPQC controller provides better harmonic distortion as compared with convention controllers.

Table-2 THD Analysis for Current

\begin{tabular}{|c|c|c|c|c|}
\hline \multirow{2}{*}{$\begin{array}{c}\text { S.N } \\
0\end{array}$} & \multirow{2}{*}{$\begin{array}{c}\text { Type of } \\
\text { Problem }\end{array}$} & \multicolumn{3}{|c|}{ THD (\%) } \\
\cline { 3 - 5 } & $\begin{array}{c}\text { Without } \\
\text { IUPQC }\end{array}$ & $\begin{array}{c}\text { With } \\
\text { UPQC }\end{array}$ & $\begin{array}{c}\text { With } \\
\text { IUPQC }\end{array}$ \\
\hline 1 & Load Current & $\mathbf{2 2 . 3 4 \%}$ & $\mathbf{2 1 . 2 4 \%}$ & $\mathbf{2 0 . 0 8 \%}$ \\
\hline 2 & $\begin{array}{c}\text { Source } \\
\text { Current }\end{array}$ & $\mathbf{2 2 . 3 4 \%}$ & $\mathbf{1 2 . 5 6 \%}$ & $\mathbf{9 . 4 \%}$ \\
\hline
\end{tabular}

Table-3 THD Analysis for Load Voltage

\begin{tabular}{|c|c|c|c|}
\hline \multirow{2}{*}{ S.No } & \multirow{2}{*}{$\begin{array}{c}\text { Type of } \\
\text { Problem }\end{array}$} & \multicolumn{2}{|c|}{ THD (\%) } \\
\cline { 3 - 4 } & & $\begin{array}{c}\text { With UPQC } \\
\text { BOA }\end{array}$ & $\begin{array}{c}\text { With } \\
\text { BOA-IUPQC }\end{array}$ \\
\hline \multirow{2}{*}{1} & $\begin{array}{c}\text { Swell at } \\
\text { feeders 1 and } \\
2\end{array}$ & $10.13 \%$ & $7.29 \%$ \\
\hline
\end{tabular}

Table-4 THD Analysis for Current

\begin{tabular}{|c|c|c|c|}
\hline \multirow{2}{*}{ S.No } & \multirow{2}{*}{$\begin{array}{c}\text { Type of } \\
\text { Problem }\end{array}$} & $\begin{array}{c}\text { With UPQC } \\
\text { BOA }\end{array}$ & $\begin{array}{c}\text { With } \\
\text { BOA-IUPQC }\end{array}$ \\
\cline { 3 - 4 } & Load Current & $\mathbf{2 2 . 1 4} \%$ & $\mathbf{2 1 . 3 4 \%}$ \\
\hline 2 & $\begin{array}{c}\text { Source } \\
\text { Current }\end{array}$ & $\mathbf{1 2 . 4 1 \%}$ & $\mathbf{8 . 3 6} \%$ \\
\hline
\end{tabular}

The THD is analyzed for the load voltage under three different cases with and without controllers. The comparative analysis for harmonic distortion is shown in table-1. From the table, it conclude that BOA based UPQC \& IUPQC controller provides better harmonic distortion as compared with convention controllers.

\section{CONCLUSION}

This paper has proposed the PQ improvement with the help of CPD, which has employed BOA based controller. The proposed controller is executed in the MATLAB/Simulink platform. The proposed method positions the optimal control pulses of the series and shunt APF depend on the source side and load side parameters through the phase angle.In the proposed method, different source side parameters, load side parameters are analyzed to calculate the phase angle for provided control signals for UPQC \& IUPQC. After that, the proposed BOA based controller has maintained the dc-link voltage. The control signals of the CPD are compensate the voltage variations and the current perturbations. The gain of the proposed manage technique is the robustness, the reliability and the adaptability for diverse forms of problems. The proposed technique has been carried out and the overall performance has been evaluated below exceptional kinds of pq problems including voltage sag and voltage swell.

\section{REFERENCES}

[1] Bruno W. França ; Leonardo F. da Silva ; Maynara A. Aredes ; MaurícioAredes, "An Improved iUPQC Controller to Provide Additional Grid-Voltage Regulation as a STATCOM", IEEE Transactions on Industrial Electronics (Volume: 62, Issue: 3, March 2015)

[2] G. Mythily, S.V.R. Lakshmi Kumari, "Power Quality Improvement by IUPQC", 2018 International Conference on Inventive Research in Computing Applications (ICIRCA)

[3] Raphael J. Millnitz dos Santos; Jean Carlo da Cunha; Marcello Mezaroba, "A Simplified Control Technique for a Dual Unified Power Quality Conditioner", IEEE Transactions on Industrial Electronics (Volume: 61, Issue: 11, Nov. 2014). 
[4] He, Jinwei, Yun Wei Li and FredeBlaabjerg, "Interline Unified Power Quality Conditioner", IEEE Transactions on Power Delivery (Volume: 22 , Issue: 1 , Jan. 2007)

[5] WashimaTasnin; Lalit Chandra Saikia, "Impact of renewables and FACT device on deregulated thermal system having sine cosine algorithm optimised fractional order cascade controller IET Renewable Power Generation (Volume: 13, Issue: 9, 78 2019)

[6] More Raju; Lalit Chandra Saikia; Nidul Sinha, "Load frequency control of a multi-area system incorporating distributed generation resources, gate controlled series capacitor along with high-voltage direct current link using hybrid ALO-pattern search optimised fractional order controller", IET Renewable Power Generation (Volume: 13, Issue: 2, 24 2019)

[7] Oliver Cwikowski; Joan Sau-Bassols; Bin Chang; Eduardo Prieto-Araujo; Mike Barnes, "Integrated HVDC Circuit Breakers With Current Flow Control Capability", IEEE Transactions on Power Delivery (Volume: 33, Issue: 1, Feb. 2018)

[8] Guoqing Li; Jing Bian; He Wang; Zhenhao Wang; Yechun Xin; Jiaxin Guan, "Interline dc power flow controller with fault current-limiting capability", IET Generation, Transmission \& Distribution (Volume: 13, Issue: 16, 820 2019)

[9] Farheen Chishti; ShadabMurshid; Bhim Singh, "Development of Wind and Solar Based AC Microgrid With Power Quality Improvement for Local Nonlinear Load Using MLMS", IEEE Transactions on Industry Applications (Volume: 55, Issue: 6, Nov.-Dec. 2019)

[10] NantheeraAnantrasirichai ; Wesley Hayes; Marco Allinovi; David Bull; AlinAchim, "Line Detection as an Inverse Problem: Application to Lung Ultrasound Imaging", IEEE Transactions on Medical Imaging (Volume: 36, Issue: 10, Oct. 2017)

[11] Ligang He; Huanzhou Zhu; Stephen A. Jarvis, "Developing Graph-Based Co-Scheduling Algorithms on Multicore Computers", IEEE Transactions on Parallel and Distributed Systems (Volume: 27, Issue: 6, June 1 2016).

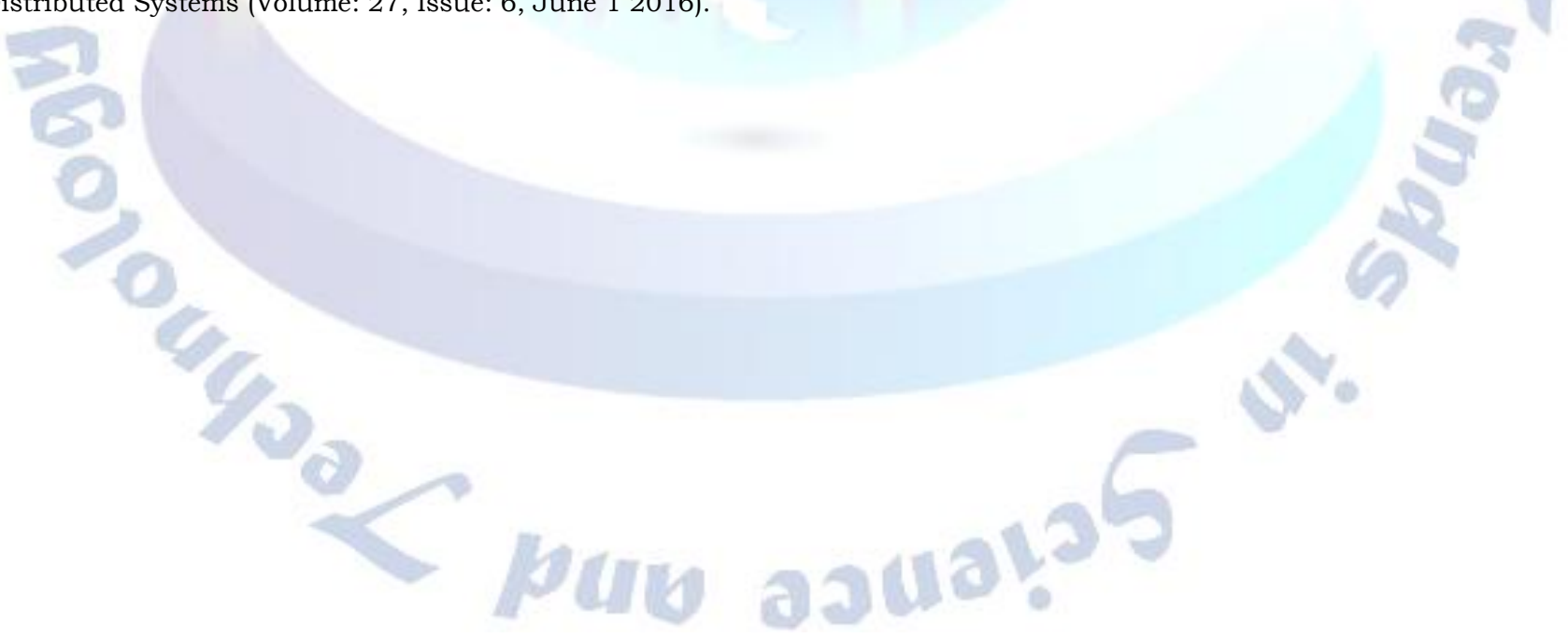

